\title{
Analysis of The Implementation of Numbered Head Together Strategy In Improving Students' Reading Comprehension at English Education Department Ganesha University of Education
}

\author{
Putu Adi Krisna Juniarta \\ English Education Department \\ Universitas Pendidikan Ganesha \\ Singaraja Bali
}

adiputu108@gmail.com

\begin{abstract}
This study aimed at improving the students' achievement in reading comprehension by using Numbered Head Together Strategy (NHT). The subjects of the study were the students of II B class of English Eduation Department, Undiksha. The study was designed in the form of a classroom action research.Each cycle involved planning, action, observation, and reflection. The data were collected by using tests, diary, and questionnaires. The result of the data showed that the students' achievement in reading comprehension improved along with the implementation of the NHT strategy. It was shown by the student's mean score in the tests. In the pre-test the students' mean score was 53.12 (sufficient). It increased up to 75.15 (very good) in post-test I and it increased to 85.50 (excellent) in post-test II. The result of the questionnaires also indicated that the students gave positive response toward the implementation of the NHT Strategy.
\end{abstract}

Key words: reading comprehension, NHT strategy

\section{INTRODUCTION}

English is a subject, which is given as a compulsory subject at Junior High school and Senior High School. The teaching of English aims at improving the students' competency on mastering the four language skills, namely reading, speaking, listening and writing. These skills are taught in an integrated way because one skill cannot be performed without the others. As it is stated by Boyle and Peregoy (2005), in everyday experience, oral and written languages used are not separated and isolated from one another, but they come together in specific communication experience. It is likely that listening may precede speaking, and reading may precede writing.

Among all of the four major skills above, reading is one of the four basic skills in English that should be mastered by students. Reading is important skill that must be thought by the teacher because through reading, students are expected to be able to get more about certain knowledge, information and pleasure.
Harmer (1998) stated that reading also provides opportunities to study language such as studying vocabulary, grammar, punctuation, and the way we construct sentences, paragraphs, and texts. Foertsch (1998) stated that there are three different definitions of learning reading. First, learning to read means learning how to pronounce words. Second, learning to read means learning to identify words and get their meaning. Third, learning to read means learning to bring meaning to a text in order to get meaning from it.

Therefore, the first point to be made about the reading process is reading comprehension, because reading without comprehending should not be called reading. The basic element for comprehension is knowledge. In other words, it can be said that in order to be able to comprehend a printed material, one should be able to use background knowledge possessed and relate it with the new information as she or he reads.

To achieve reading comprehension, there are several important components 
that the students should master. Those components can be categorized as the basic competencies that the students should achieve, they are: 1) the ability to obtain general and specific information from the written text, either it is explicitly or implicitly stated, 2) the ability to obtain main ideas stated in a text whether explicitly or implicitly, 3) the ability to guess the meaning of the words, phrases, or sentences based on the context, and 4) the ability to understand reference devices used in a text (Candiasa: 2008).

Based on the writers' observation that was conducted at II B class of English Education Department, students have problems in comprehending a paragraph or text particularly in finding the main idea, specific information, textual references, and words meaning. This main problem might appear because of many factors. The factors were concerned with the ineffective teacher's pre-reading strategy, students' lack of vocabulary, and students' lack of knowledge about the topic.

One of the obvious factors was the ineffective pre-reading strategy which was applied by the lecturer. For example the lecturer just gave a reading model to the students first, and then the students were asked to read through the text before they tried to answer several questions about the text. Besides, lecturer directly used the text in the book without any effort to find any other alternative interesting texts for the students. This monotonous activity seemed boring to the students and they were also not well motivated to activate and recall their prior knowledge and vocabularies to the text that would be discussed.

Because of the problems above which are faced by the students, the results of the reading test was unsatisfying, in that, the mean score was only 53.12 from the maximum score is 100. The mean score could be categorized as unsatisfying.

Referring to the problems above, the researcher was interested in conducting a study, which was intended to improve students' achievement in reading comprehension at II B class of English Education Department, Undiksha. The researcher proposes a solution to overcome the problem to improve the students' achievement in reading comprehension by using Numbered Head Together (NHT) Strategy. It is mainly focused on the cooperative learning activity.

Numbered Head Together (NHT) which is developed by Kagen (1993) is a strategy to involve more students in the review of materials covered in a lesson and to check their understanding of a lesson's content. NHT is a cooperative learning strategy that holds each student accountable for learning the material. Students are placed in groups and each person is given number in this case from one to the maximum number in each group. The teacher poses a question and students put their heads together to figure out the answer. The teacher calls a specific number to respond as spokesperson for the group. By having students work together in a group, this strategy ensures that each member knows the answer to problems or questions asked by the teacher. Because no one knows which number will be called, so all team numbers must be prepared. This cooperative learning strategy promotes discussion on both individual and group accountability. This strategy is beneficial for reviewing and integrating subject matter. Students with special needs often get benefit when this strategy is used. After direct instruction of the material, the group supports each member and provides opportunities for practice, rehearsal, and discussion of content material.

In implementing NHT strategy, here are four steps will be applied namely:

a. Numbering

Lecturer divided students into three to five member teams and have them number off so each student on a team has a number between one and five.

b. Questioning

Lecturer asked students a question. Question can vary. They can be very specific and in question form. 


\section{c. Head Together}

Students put their head together to figure out and make sure everyone knew the answer.

d. Answering

The teacher called a number and students with that number raise their hands and provided answers to the whole class.

In addition, there are several benefits in applying this strategy such as: this cooperative learning strategy promotes discussion on both individual and group accountability, beneficial for reviewing and integrating subject matter, and providing "think time" increases quality of students' responses..

From the benefits above, it can be seen that 'NHT' strategy is a flexible strategy that can be used at a variety of levels because it provides an opportunity for all students to share their thinking with other students, in turn, increases their sense of involvement in classroom learning.

Furthermore, some experts had proved the influences of NHT strategy in teaching reading. NHT has been proven to be helpful to improve the students' achievement in comprehending material in the junior high school students (Ayuningtyas: 2015). She also made a research in senior high school which resulted that NHT could effectively improve the students' achievement in comprehending material.

Purnomo (2012) also applied this strategy for junior and senior high school students. They found that their students were more motivated in reading. This strategy gave opportunity to them to access their prior knowledge, learnt from teacher's modeling and the students gave their own feedback and more conversations among their friends.
Based on the above explanation about the strengthen which is derived from the use of Numbered Head Together (NHT) strategy, the study was intended to find out whether the implementation of Numbered Head Together (NHT) strategy can improve the students' achievement in reading comprehension. The researcher tried to use Numbered Head Together (NHT) strategy to improve students' achievement in reading comprehension at II B class of English Education Department in Undiksha.

\section{METHOD}

The purpose of the study was to improve the students' achievement in reading comprehension of the implementation of NHT Strategy. Some procedures were designed as follows:

\section{Subject of the Study}

The subjects of this study were the students of II B class at English Education Department in academic year 2015/2016. There were thirty seven students in the classroom that consisted of seventeen males and twenty females. Based on the prior observation and preliminary interview, the students were selected because the student had problems in reading comprehension.

\section{Research Design}

In this study, the researcher used the classroom action research procedure. According to Kemmis \& Mc. Taggart (1998), an action-based research is a cyclic process that continuously conducted by the researcher until the minimum standard or passing score is reached. The cyclic consists of planning, action, observation, and reflection.

A clear diagram of the research design can be seen below 


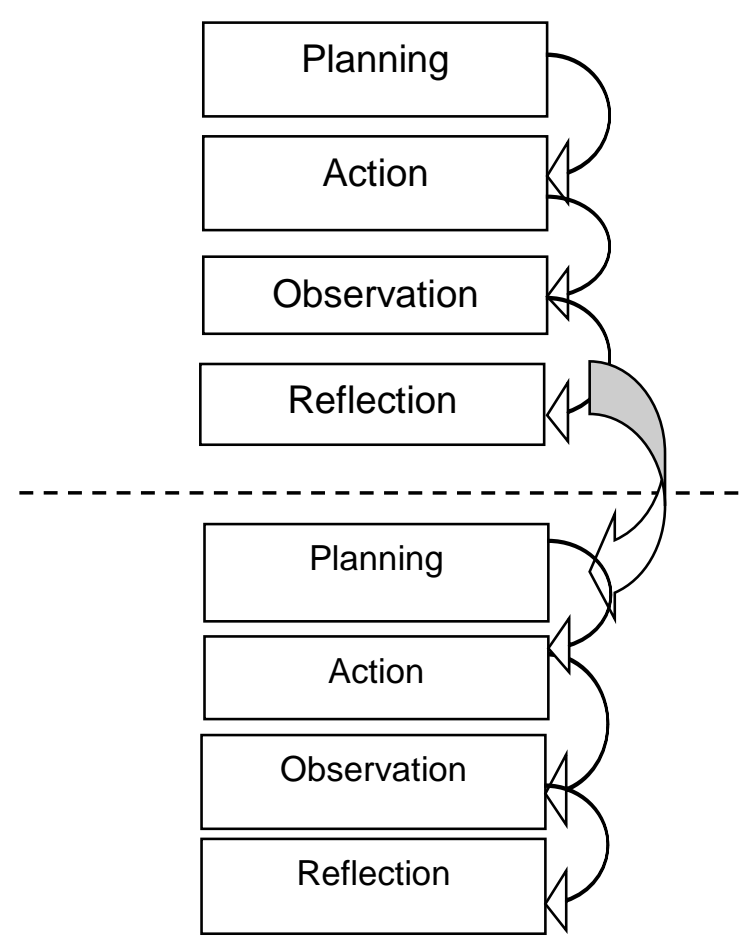

\section{Cycle 1}

The next cycle will be conducted if the study was failed or not all of the students can reach the success indicator

Next Cycle

Figure 1. Research Design

Based on the figure, there were two cycles that would be employed in this study and each cycle involved planning, action, observation, and reflection.

1. Planning

Before conducting the action, there were some preparations that had been designed, namely teaching scenario, materials, questionnaires, reading tests, teaching diary.

\section{Action}

The plan which had been made was implemented at this stage. The researcher did all the planning in the classroom and the class management was done based on the teaching scenario.

3. Observation

It refers to process of observing the action. The observation was carried out both during and after the action. During the action, the researcher observed the classroom situation and the students' behaviors in the diary. After the action, the pos-test and the questionnaires were given to the students then the result of the post- test and the questionnaires were analyzed at this stage. Analyzing students post-test was intended to find out the result of the action whether the students' comprehension in reading improved or not. On the other hands, analyzing the results of the questionnaires was intended to know the students' responses toward the action.

\section{Reflection}

Reflection refers to the diagnosis of the effect of the treatment. It was done at the end of the action in order to identify the strengths and weaknesses of the action. In this stage, the researcher found out the reasons of the students' failure. The researcher could also decide whether the next cycle is needed to be conducted. Reflection was also served as feedback to improve the next action.

\section{Instrumentation}

The researcher used some instruments in collecting the intended data. They were tests, diary, and questionnaire. Test 
There were two kinds of reading tests: pre-test and post-test. The pre-test was administered before giving the action in order to know the students' initial achievement in reading comprehension. Meanwhile, the post-test was administered at the end of each cycle in order to know the students' achievement in reading comprehension after the action given. The post-test was administered in order to know whether or not the students' achievement has improved
Diary

The diary was used by the researcher in order to take a note the classroom activities during the learning process. It was used to record students' behaviors and the condition of the class during the teaching learning activities. The data from the researcher diary was used to know the students' problems during the teaching learning process, so that the researcher could make a decision about what should be done to minimize these problems in order to get better result in each cycle. The form of the diary could be shown as follows:

Table 1. The Diary Format

\begin{tabular}{llllll}
\hline No. & $\begin{array}{l}\text { Teacher's } \\
\text { Activity }\end{array}$ & $\begin{array}{l}\text { Students' } \\
\text { Activity }\end{array}$ & Time & $\begin{array}{l}\text { Students' } \\
\text { Response }\end{array}$ & $\begin{array}{l}\text { Classroom Notes } \\
\text { Situation }\end{array}$ \\
\hline
\end{tabular}

\section{Questionnaire}

The questionnaires were delivered twice. The first one was administered after the pre-test. It was used to know the problems faced by the students and the second one was given at the end of each cycle in order to know students' responses toward the implementation of the strategy. The blue print of questionnaire could be seen as follows:

Table 2. Blueprint of the Questionnaire

\begin{tabular}{clcc}
\hline No & \multicolumn{1}{c}{ Question Categories } & $\begin{array}{c}\text { Number of } \\
\text { Items }\end{array}$ & $\begin{array}{c}\text { Item's } \\
\text { Number }\end{array}$ \\
\hline 1 & The students' attitude & 1 & 1 \\
\hline 2 & The role of the treatment towards the students & 5 & $2,3,4,5,6$ \\
\hline 3 & The students' motivation & 1 & 7 \\
\hline 4 & The researcher's way in applying the strategy & 4 & $8,9,10,11$ \\
\hline 5 & The relevance of the test & 1 & 12 \\
\hline & Total Items & 12 Items & \\
\hline
\end{tabular}

\section{Procedure of Data Collection}

The action in this study was conducted in accordance with the procedures, which consist of planning, action, observation, and reflection. The procedure could be seen as follows:

\section{Pre-Test}

Pre-test was used to examine the students' achievement in reading comprehension before the action was given. The test consisted of 20 items. Then the result of pre-test would be used as reference of conducting the research

\section{Cycle instruction}

Cycle instruction was carried out in three sessions. Two sessions were intended for action and one session was intended for the test. Those activities in each session can be seen as follows: 
Table 4. The Four Stages of the Data collection

\begin{tabular}{|c|c|c|c|}
\hline Planning & Action & Observation & Reflection \\
\hline $\begin{array}{l}\text { 1. Repairing } \\
\text { teaching } \\
\text { scenario. } \\
\text { 2. Preparing } \\
\text { instruments such } \\
\text { as post-test, } \\
\text { diary, and } \\
\text { questionnaires. }\end{array}$ & $\begin{array}{l}\text { 1. Conducting pre- } \\
\text { activities. } \\
2 \text {. Conducting } \\
\text { whilst-activities } \\
\text { 3. Conducting } \\
\text { post-activities. }\end{array}$ & $\begin{array}{l}\text { 1. } \begin{array}{l}\text { Observing } \\
\text { classroom } \\
\text { situation or } \\
\text { students' } \\
\text { behavior. }\end{array} \\
\text { 2. Observing the } \\
\text { process of } \\
\text { post-test } \\
\text { 3. Observing the } \\
\text { process of } \\
\text { questionnaires. }\end{array}$ & $\begin{array}{l}\text { 1. Reflecting } \\
\text { the strengths } \\
\text { of the } \\
\text { teaching } \\
\text { learning } \\
\text { process. } \\
\text { 2. Reflecting } \\
\text { the } \\
\text { weaknesses } \\
\text { of the } \\
\text { teaching } \\
\text { learning } \\
\text { process }\end{array}$ \\
\hline
\end{tabular}

\section{A. Data Analysis}

The data were obtained from the result of the pre-test and post-test. The pre-test was done before the implementation of the action. The post-test would be showed the result of the action over the students' learning. The result of the post test was compared to the result of the pre-test in order to determine the students' learning improvement. If the mean score of the post-test was higher than the mean score of the pre-test, it means that the action was effective to improve the students' competence in reading comprehension.

The types of data gather in this study were in the form of qualitative and quantitative data. The qualitative data were gathered from the researcher's diary, the result of the questionnaire being applied during the action in each cycle. While, the quantitative data were gathered from the result of pre-test, post-test of each cycle. The result of the test was analyzed descriptively, in order to find out the mean score of pre-test and post-test of each cycle.

\section{Descriptive Analysis of the test}

The descriptive analysis was conducted to investigate the problem by finding out the mean score. The formula was adapted from Masidjo (1995) in Candiasa (2008:37). The score of each student was calculated by using the following formula

$$
X=\frac{\text { The total number of items answered correctly }}{\text { The total number of item }} \times 100
$$

The mean score of the whole students was calculated as in the following formula

The total score obtained by the students

$$
X=\frac{\text { The total number of students }}{100 \%}
$$




\section{Data Analysis of the Questionnaires}

An appropriate score schema in the Likert scale was associated with each of possible response (Clark, 1999). The score for each option response of the questionnaires used in this study ranged from 1 to 5 (option $A=5, B=4, C=3, D=2$, $E=1)$. The score for each option was summed in order to get the total score and the mean score. The formula which is used to find the mean score could be seen as follows:

$$
\begin{array}{cl}
\text { Note } & : M \quad=\text { mean score } \\
\mathrm{X} & =\text { midpoint } \\
\mathrm{f} & =\text { frequency } \\
\mathrm{N} & =\text { number of students }
\end{array}
$$

$$
M=\frac{\Sigma f x}{N}
$$

A criterion was needed to interpret the mean score. Dantes (1983:78), as cited in Wardhani (2004:76), used the formula below to interpret the mean score of the questionnaires. The criteria could be seen as

follows:

Figure 2. The Criteria to Interpret the mean score

Note:

$\mathrm{Mi}($ Ideal mean score $)=1 / 2 \quad \mathrm{X} \quad$ (ideal maximum score + ideal minimum score) SDi (Ideal standard deviation) $=1 / 6 \quad x$ (ideal maximum score - ideal minimum score)

Ideal Maximum score was obtained by multiplying the highest score for the response with the total number of items in the questionnaires. In this study the highest score for the response was 5 and the total number of the items of the questionnaires was 12 . So the ideal maximum score became 60 .

Ideal minimum score was obtained by multiplying the lowest score for the response with the total number of items in the questionnaires. In this study the lowest score for the response was 1 and the total number of the items of the questionnaires was 12. So the ideal maximum score became 12 .

\section{Success Indicator}

\section{A. Success indicator of the test}

The study would be considered successful if $100 \%$ of the students had passed reading course by good criteria. The students' level of mastery used was stated as follows: 
Table 6. The Level of Mastery on Reading Comprehension

\begin{tabular}{cc}
\hline PERCENTAGE & CRITERIA \\
\hline $85 \%-100 \%$ & Excellent \\
$70 \%-84 \%$ & Very Good \\
$60 \%-69 \%$ & Good \\
$50 \%-59 \%$ & Sufficient \\
$0 \%-49 \%$ & Insufficient \\
\hline
\end{tabular}

(Masidjo, 1995)

B. Success indicator of the questionnaire

The study would be considered successful if the students had positive response of the implementation of $\mathrm{NHT}$

The criteria of the students' response in this study could be seen as follows:

$$
\begin{aligned}
& \mathrm{Mi}=1 / 2 \times(60+12)=36 \\
& \mathrm{SDi}=1 / 6 \times(60-12)=8
\end{aligned}
$$

\section{Finding and Discussion}

Due to the fact that this study was a classroom action research, there were two findings obtained namely, the quantitative and the qualitative findings. The quantitative findings could be seen from the students' result of pre-test and posttests while the qualitative findings could be seen from the result of questionnaires and students' activity.

The findings were discussed within the three main stages of the study, that is, the findings of the preliminary observation, cycle 1 , and cycle 2 .

\section{Finding on Pre-Observation}

The result of the pre-test showed that the students had low achievement in reading comprehension. The students' mean score was 53.12 and categorized as sufficient. Looking at the result of the pretest, it was considered important to give some kinds of treatments to the students in order to help them achieve improvement on reading comprehension.

On the other hand, the questionnaire was distributed after conducting pre-test. After calculating the questionnaires' scores, it was found that the highest questionnaires score of the students was 36 and the lowest strategy. The positive response was reached if the mean score of students could be categorized as positive response in the criteria of the questionnaires score above.

$$
\begin{aligned}
& 44-60=\text { positive } \\
& 28-<44=\text { neutral } \\
& 12-<28=\text { negative }
\end{aligned}
$$

Figure 3. The Criteria of the questionnaire score

score was 22 . In addition, the mean score of questionnaire in pre test was 27.74 , so the criterion was negative. It could be concluded that the students had problems in reading class especially about students' response when joining reading course. From the result of pre-observation, the researcher decided to give treatment to the students by implementing NHT strategy in teaching reading. It was hoped that the implementation of NHT strategy could overcome students' reading problems and improved their achievement on reading comprehension.

\section{Findings on Cycle I}

Cycle I was carried out in three sessions in which two sessions were intended for action and one session was for test. The questionnaire was administered at the end of the test. The post-test was conducted to measure whether the students had gained improvement after being given the treatment using NHT. The students' mean score was 75.15 , which was categorized as very good. It improved 22.03 points from the score in pre-test. 
In the post-test I there were 13 $(48.15 \%)$ students who got 'very good' result, 13 (48.15\%) students who got 'good' result and 1 (3.7\%) students who got 'sufficient' result. Although the students had made improvement, there was a student could not reach the success indicator. Because of that the following cycle would be conducted in order to make all of the students be able to reach the success indicator.

However, the questionnaire which was given in the end of the test was aimed at knowing the students' response toward the implementation of the NHT strategy. The mean score of questionnaire in cycle I was 44.11 , so the criterion was positive. It could be concluded that the students gave positive response toward the application of NHT strategy in reading class.

Although the questionnaires' mean score of the students reached positive criteria, there were some of the students getting neutral criteria. There were only 14 $(51.85 \%) \quad$ students giving positive response and 13 (49.15\%) students giving neutral response in the questionnaire of cycle I. Because there were only few of the students giving positive response, the following cycle would be conducted in order to make most the students be able to give positive response to the implementation of NHT strategy.

From the result of Post-Test and questionnaire in cycle 1 , there was an improvement of the students' achievement in reading comprehension. The improvement on students' achievement in reading comprehension was caused by the implementation of NHT strategy in the classroom. Each step in the implementation of NHT strategy helped the students to understand the text deeply. The pre-activity also helped the students to activate their background knowledge. The improvement of the students' achievement in reading comprehension in Post-Test I was also reflected by their responses of the questionnaire. In general, the students showed positive attitude toward the implementation of NHT strategy.

Although there were improvement of achievement of reading comprehension and students' response, there were also some problems which appeared during the teaching and learning process. Most of the students still could not participate well in the activity. In the first meeting, some students felt confuse with the activity since the activity was new for them.

Regarding to the reflection of cycle I, the next cycle was continued. Several modifications were made in cycle II. First, the vocabulary items were taught by asking them to find out the meaning of the difficult words by consulting with the dictionary. If they still did not understand about the meaning of the difficult words, the teacher had to give the correct meaning of the words for them. This was intended to motivate them in learning the vocabularies. Second, the teacher asked the students to work in groups. Each group consisted of 4 to 5 students. The grouping was intended to help the students became confident with their answers. Third, the students who got low score in post test 1 were asked to answer the questions in questioning section intensively. It was done to make them more understand about the text given by giving them more chances.

\section{Finding On Cycle 2}

Cycle II was also carried out in three sessions in which two sessions were intended for action and one session was for test. The questionnaire was administered at the end of the test. The post-test II was made to know whether the implementation of NHT strategy after being modified could help the students to gain some improvements in reading comprehension.

After activity in cycle 2 conducted, the students' mean score of the reading test improved relatively better than their achievement in post-test I. The students' mean score was 85.50, which could be categorized as excellent. It improved 10.45 points from the mean score in cycle I. In the post test 2, it was also found that there were $11(40.74 \%)$ students who got excellent result, 14 (51.86\%) students who got very good result, only $2(7.40 \%)$ students who still got good result. 
In line, the students' response of the implementation of NHT strategy improved relatively better than their response in the questionnaire of cycle I. The students' questionnaires' mean score was 47.00, which could be categorized as positive. It improved 2.89 points from the mean score in questionnaire of cycle I. There were 27 $(100 \%)$ students giving positive response Because there were all of the students giving positive response, it could be concluded that the implementation of the NHT strategy helped and motivated them when joining reading class.

From the result of post-test and questionnaires in cycle 2, it could be concluded that the students' achievement in reading comprehension improved and students' response were positive. The students' mean score was 80.5 and it was categorized as 'good'. It increased 10.45 points compared to the result of post-test 1. The students' improvement in the result of post test 2 was also in line with their positive responses toward the application of NHT strategy.

The improvement of the students' score and response were caused by some modifications that were done in the application of NHT strategy in cycle 2. The researcher could see that the students became more active compared to the first cycle. The students became more confident and comfortable when sharing their ideas. The students' participation could be seen when they worked in-group.

As a result, the students' mean score of the test and students' response in cycle 2 had already passed the standard indicator. It means that the researcher decided to stop the study until cycle 2 .

\section{Discussion}

Since the purpose of this study was to improve the students' achievement in reading comprehension and discussed how the improvement was gained by the students during the treatments took place. The improvement could be seen from the results of the analysis of the researcher's diaries, the questionnaires and the tests.

From the researcher's diaries, it was known that there were changes in the students' behavior during the teaching and learning process. In cycle I, some students were passive and most of them felt unconfident when giving the answer. They had tendency to wait for their friends' answer and just agreed the answer. Moreover, the students also faced problem in understanding the words of the text given. Some of them could not find the meaning of difficult words. It made the students cannot understand about the text and cannot find the whole information of the text.

In cycle II, the researcher made some modifications in teaching reading, in order to solve the students' problems that were faced in cycle I. First, the vocabulary items were taught by asking them to find the meaning of the difficult words by consulting with the dictionary. If they still did not understand about the meaning of the difficult words, the teacher told them the correct meaning of the words. This was intended to motivate them in learning the vocabularies. Second, the students were asked to work in groups. Each group consisted of 4 to 5 students. The clever students, who had big score in post test 1 , were separated in each group. It was done to help the other students who had low score in post test 1 in understanding the text given. Beside that, the grouping was intended to help the students became confident with their answers. In addition, it could minimize their anxiety of making mistakes because they had group that could support them. Third, the students who had low score in post test 1 were asked to answer the questions intensively in questioning section. It was done to make them more understand about the text given. The questions were more about specific information because in the result of post test 1 many students could not answer the question which about specific information.

As a result, the teaching and learning process ran well in which more students became active in the activity. The result of the questionnaire also showed that they gave positive response toward the implementation of the NHT strategy. The success of the action could be seen from the students' result of the tests. 
In terms of the academic factors, the students' improvement was closely related to NHT strategy's nature for facilitating the students in reading comprehension. Dealing with the nature of $\mathrm{NHT}$, the students' responses were generally positive, in which most students thought that NHT could really useful in helping them in reading. It could be concluded that NHT strategy is one of many innovative strategies which can help the students when joining reading class. This strategy is developed by Kagen (1993) to involve more students in the review of materials covered in a lesson and to check their understanding of a lesson's content. "NHT" is a cooperative learning strategy which holds each student accountable for learning the material.

\section{Conclusion and Suggestion}

Based on the previous findings and discussion, it could be concluded that the implementation of NHT strategy could help the students, especially the students of II B class of English Education Department to improve their achievement in reading comprehension. In line with the students' improvement of the achievement in reading comprehension, the result of the questionnaires revealed that the students gave positive response to the implementation of NHT strategy. It is one of many innovative strategies which can help the students when joining reading class.

Relating to that fact, other researcher is suggested to conduct further study on the implementation of NHT strategy in longer period of time for the purpose of improving students' achievement in reading comprehension.

\section{References}

Foertsch.1998. Definition of Reading. Available at "http://www.readingskill.com/index.ht $\underline{\mathrm{ml}}$, Accessed on 3rd July 2015

Harmer, Jeremy. 1998. How to Teach English. London: Longman.

Kemmis, Stephan and Mc. Taggart, Robin. 1988. The action Research Planner. Victoria: Deakin University.
Kagen, Spencer. 1993. "Kagan structures for emotional intelligence. Available at

http://www.kagancooplearn.com/new sletter/1001/index.html. Accessed on 3rd February 2015.

Peregoy, F. 2005. Reading, Writing, and Learning in ESL. Available at http://www.pearsonhighered.com/pro duct/Peregoy-Reading-Writing-andLearning-inESL/9780132685153.html. Accessed on 2nd March 2014

Purnomo, S. 2012. Improving The Students' Reading Comprehension Through Numbered Heads Together Technique. Journal on English as Foreign Language.2(2).175-184

Wardhani, Ni Ketut Srie Kusuma.2004. Study Tentang Hubungan Pola Asuh Orang Tua, Interaksi Media Massa, dan Tingkat Religiusitas dengan Sikap Terhadap Perilaku Agresif Siswa Remaja di SMU

Negeri 3 Singaraja Kabupaten Buleleng TAhun 2003/2004. Unpublished Dissertation of IKIP Negeri Singaraja. 